\title{
Implementation of Dolanan Bocah to Improve The Speaking Proficiency of Primary School Students
}

\author{
Biya Ebi Praheto \\ Department of Primary Teacher Education, Universitas Sarjanawiyata Tamansiswa, Yogyakarta, Indonesia
}

\begin{tabular}{|c|c|}
\hline Article Info & ABSTRACT \\
\hline Article history: & \multirow{9}{*}{$\begin{array}{l}\text { This research aims to improve the speaking proficiency of } 5 \text { th grade students } \\
\text { at SD Negeri Mendungan } 2 \text { Yogyakarta by utilising dolanan bocah } \\
\text { (traditional games) in the learning process. This classroom action research } \\
\text { was conducted in two cycles. The subjects of this action research are the } 5 \text { th } \\
\text { grade students of SD Negeri Mendungan } 2 \text { Yogyakarta in the academic year } \\
2015 / 2016 \text {. There were } 30 \text { students consisting of } 16 \text { female and } 14 \text { male } \\
\text { students in the study. This study differs from previous research. This can be } \\
\text { seen from the research action research that integrates dolanan bocah in } \\
\text { learning Bahasa Indonesia. The implementation of dolanan bocah } \\
\text { corresponds with a significant improvement in the students' speaking } \\
\text { proficiency. The improvement can be evidenced by the disparity of scores } \\
\text { obtained in cycle I and II. In the first cycle, the average score was } 71.9 \text { with a } \\
\text { classical completeness of } 63.3 \% \text {, while in cycle II, the average score } \\
\text { increased to } 82.4 \text { with a classical completeness of } 83.3 \% \text {. }\end{array}$} \\
\hline Received Nov 23, 2017 & \\
\hline Revised May 12, 2018 & \\
\hline Accepted May 26, 2018 & \\
\hline Keywords: & \\
\hline Dolanan Bocah & \\
\hline Traditional Games & \\
\hline Factual Speaking & \\
\hline Primary School & \\
\hline
\end{tabular}

Copyright $@ 2018$ Institute of Advanced Engineering and Science. All rights reserved.

\section{Corresponding Author:}

Biya Ebi Praheto

Departement of Primary Teacher Education,

Universitas Sarjanawiyata Tamansiswa,

Jl. Batikan, Tuntungan UH III/1043 Umbulharjo, Yogyakarta, 55167, Indonesia.

Email: biya.ebi@ustjogja.ac.id

\section{INTRODUCTION}

Culture cannot be separated from language. This is because language is one of the seven elements of universal culture. Language arises as a result of a community's need to build relationships and socialize. This is in accordance with a sociolinguistic approach, which states that there is a strong relationship between the development of language and the development of society. Besides this, language has many variations and acts as a means of communication and as an element of group identity [1]. Therefore, language cannot be separated from culture, nor can it be separated from the development and teaching of Bahasa Indonesia in schools, especially at the elementary level.

Indonesian (Bahasa Indonesia) has been growing rapidly in the community as a mother tongue. This is happening not only in urban areas, but also in rural ones. Nevertheless, Bahasa Indonesia learning at school is experiencing a number of problems. One problem is that Bahasa Indonesia is a rather difficult language for the learner to grasp. This is due to various factors arising from the teachers, students, and policies related to the curriculum and materials. Language, which is principally a communication medium, is mostly taught through the principle of discourse review. This is obvious from the scores obtained by students after completing examinations, in which they get lower scores in Bahasa Indonesia than in any other subject tested. In addition, their motivation in the learning process becomes a critical factor in the process of transferring and embedding the materials delivered by the teachers.

Conventional and monotonous learning is remarkably influential on the results achieved by the students. There is also the view that Bahasa Indonesia is a less important subject, so that in practice, many students underestimate it. In line with this, Muslimin [2] explained that this fatal assumption causes some 
students who take the national exam (UN) to fail. As a result, sometimes they are not enthusiastic enough to explore Indonesian literature and sciences.

One aspect of language skills that is considered difficult is speaking. Speaking is an ability to articulate sounds or words in order to express thoughts, ideas, and feelings [3]. Similarly, Arsjad and Mukti [4] argued that the ability to speak is the ability to pronounce sentences to express, state, and convey thoughts, ideas, and feelings. Difficulties in learning how to speak are caused by the various factors aforementioned.

Based on the results of preliminary observations made in SD Mendungan 2 Yogyakarta, various students' problems in learning how to speak can be identified. Most students find it difficult to share their ideas to others verbally. They are only able to express their ideas in just one or two sentences. In addition, their motivation is still very low, which can be seen clearly from the students' behavior during the delivery of materials by the teacher. They do not fully concentrate and are not enthusiastic in the learning process. It shows the importance of innovative learning to improve their motivation, as stated by Park [5] in his research entitled Relationship between Motivation and Student's Activity on Educational Game which suggested that there is a difference in intrinsic motivation between the learners who play games during the learning and those who do not. It shows that the integration of games, media, and so forth is very influential in the learning process undertaken by the students.

In this regard, specific strategies are required that cover all learning components. The relationship between the students, teachers, and learning materials cannot be separated from one another. All three are interlinked to support the achievement of the objectives of speaking Bahasa Indonesia. As hard as any speaking materials taught may be, the teacher should be able to convey them accurately and clearly to the students, and the students should also be able to understand what the teacher has presented. Therefore, appropriate and innovative learning models are needed.

Learning to speak Bahasa Indonesia in primary school plays an important role in mastering general speaking abilities for a learner. This is because at primary school age, students can absorb the materials to their full extent and store what they learnt in their long-term memory. During primary school, children are expected to acquire basic knowledge considered essential for their preparation and adaptation to life as an adult. In addition, primary school students are those who are undergoing a developmental stage of childhood before entering into early adolescence. Primary school-aged children are expected to acquire certain skills that include: a) self- sufficiency skills; b) social skills; c) academic skills, and e) playing skills [1]. At this age, children are able to play games suitable for their age.

On the other hand, primary school is also known as an intellectual period. This is due to the desire and openness of the children to gain knowledge and experience. Playing is meaningful for a child, as playing is a serious but also very fun activity. When a child is allowed to play freely, according to his interests and pace, he can practice his skills optimally. Therefore, to learn Bahasa Indonesia at primary school, games can be integrated in the learning process. Play is a medium for children to explore their world, from what they do not understand to what they know, and from what they are unable to do to what they are capable of doing. By understanding the meaning of play for children, it can be concluded that play is a necessity for them.

By designing a particular session to be implemented while playing, then the children will learn according to the demands of their developmental level. Semiawan [6] explained that there are two important aspects related to child development: 1) cognitive development. The children at this age show that they are at a preoperational to concrete operational stage, and 2) brain functions. Both left and right hemispheres have different functions. The left hemisphere has functions, features, and responses for logical, orderly and linear thinking. Contrastingly, the right hemisphere is primarily developed to think holistically, imaginatively, and creatively. When a child learns many formal things (such as rote learning) at a very young age, his left hemisphere that functions to think linearly, logically, and regularly will develop fully, but this often results in a less-developed right hemisphere. As a result, in the future he may tend to have a hostile attitude toward his fellow friends or others. This case shows unhealthy mental growth.

Considering the various issues above, classroom action research was conducted to improve the students' speaking ability by implementing dolanan bocah in the learning process. Related classroom action research was previously conducted by Marzuki [7] entitled Improving the ELF Learners' Speaking Ability through Interactive Storytelling. Marzuki's study shows the enhancement of ELF speaking ability using a storytelling implementation strategy. Meanwhile, this research implements dolanan bocah. Dolanan bocah is a Javanese term for traditional games for children. In Indonesian, it is called permainan tradisional. Dolanan bocah is integrated in the learning to motivate the students and also to introduce them to national culture in order to preserve it. Dolanan bocah integrated in learning Bahasa Indonesia is expected to help provide the students with a more in depth understanding of the lesson while also incorporating the cultural values of the community in the academic sphere. This is because dolanan bocah is a result of existing and longstanding culture in Indonesian society.

EduLearn Vol. 12, No. 4, November 2018: $685-689$ 


\section{RESEARCH METHOD}

This research used qualitative research using the Classroom Action Research strategy and consisted of two cycles conducted over a five-month period, from January to May 2016. This research was conducted at SD Negeri Mendungan 2 Yogyakarta. The subjects of this action research were the 5th grade students of SD Negeri Mendungan 2 Yogyakarta in the academic year 2015/2016. There were 30 students, consisting of 16 female students and 14 male students. The data was collected based on relevant information about the process of learning to speak fluently, motivation to learn, and the students' ability in speaking and delivering factual problems, as well as the teachers' ability to prepare lesson plans that would implement the learning outcomes, including the use of learning strategies and media in the classroom.

The research data was collected from various sources including: a) information or informants, i.e. the students and the teachers; b) place and event of learning activities; and c) related documents or archives. The techniques used to collect the data above included observation, questionnaires, interviews or discussions, document review, and tests. Meanwhile, the analysis technique applied in this research to check the validity of the data was triangulation of the data sources.

This research was considered successful if the average scores in the last cycles were above the scores of Minimum Criteria of Mastery Learning (Indonesia: KKM), and 80\% of the students achieved scores higher than the KKM. The research design was as follows: In class action research (PTK), there was an assessment process cycle consisting of four stages: planning, action, observation, and reflection.

\section{RESULTS AND ANALYSIS}

Based on the research conducted, it can be proven that the application of traditional games can optimize the language learning of 5th grade students, related to their ability to speak. The cycle I and II activities can be summarized as follows:

\subsection{Improvement of Speaking Proficiency}

The speaking proficiency of the 5th grade students of SD Negeri Mendungan 2 Yogyakarta improved significantly in terms of both the process and the results. The improvement can be seen from the test scores achieved. The development of speaking proficiency of the 5th grade students of SD Negeri Mendungan 2 Yogyakarta can be seen from Table 1.

Table 1. Improvement of Speaking Proficiency

\begin{tabular}{llcc}
\hline No. & Achievement Criteria & Cycle I & Cycle II \\
\hline 1. & Students' scores $<70$ & 11 students & 5 students \\
2. & Students' scores $\geq 70$ & 19 students & 25 students \\
3. & Lowest score & 48 & 64 \\
4. & Highest score & 92 & 96 \\
5. & Average & 71.9 & 82.4 \\
6. & Classical Completeness & $63.3 \%$ & $83.3 \%$ \\
\hline
\end{tabular}

\subsection{Discussion of the Result}

Based on the problems formulated in the introduction section and the explanation of the research results, the following paragraphs will discuss the results including the speaking proficiency of the 5 th grade students of SD Negeri Mendungan 2 Yogyakarta.

From preliminary observations prior to the action or pre-cycle sections, the students found it difficult to learn to speak. It also appears from the questionnaire that all students stated that speaking lessons are difficult. However, after the action was applied, there were only a few students who still said that speaking was a difficult lesson. In addition, in the preliminary observation, it was also found that students' difficulties in learning to speak were especially in terms of expressing opinions or ideas.

Following the implementation of dolanan bocah, the speaking ability of the 5 th grade students improved markedly. This can be seen from the test results, where they were able to express opinions or ideas related to factual problems orally. The success rate of this research is significant. The scores obtained by the students from each cycle have improved satisfactorily. In cycle I, the highest score was 92, achieved by one student. The lowest score was 48, achieved again by only one student. Meanwhile, the average score was 71.9. Compared with the first cycle, the average score of cycle II increased by 10.5 points from 71.9 to 82.4. Two students achieved the highest score in cycle II of 96, and the lowest was 64, achieved by three students.

Many things, particularly the learning process, influenced the improved ability of the 5th grade students in speaking. The learning process conducted by the teachers will affect the students' level of achievement. In the previous learning session, the teacher taught speaking using conventional methods

Implementation of Dolanan Bocah to Improve The Speaking Proficiency of Primary ... (Biya Ebi Praheto) 
without using any interesting educational media or teaching techniques. It made the speaking materials difficult to be understood and not well conveyed to the students, so that as a result many students could not express their opinions or ideas verbally. As mentioned by Nurhayati [8], one of the key determining factors of successful learning is the use of learning strategies. Therefore, the teachers should be able to choose and use specific strategies that are appropriate to the desired learning objectives to be achieved.

The mentality of the students also influences their learning significantly. Many of them are unmotivated. This condition makes them reluctant to learn and indifferent to the speaking materials. A monotonous learning process with difficult materials also makes the students become uninterested and unhappy. Such conditions impact their ability to effectively learn how to speak. A lack of motivation in learning results in poor speaking proficiency. It is also in line with research conducted by Wang [9] entitled Investigating the Impact of Using Games in Teaching Children English. In general, his study states that there is a significant relationship between integrated games in the learning process and the learners. In addition, the games also have significant impacts on the students' learning motivation and their mastery of English vocabulary.

Similarly, the learning process utilisedby the research completed in both cycle I and II, conducted with the implementation of dolanan bocah had an impact on creating a more exciting and enjoyable learning process for the students. They became more enthusiastic to participate in the lesson even though the materials taught were rather difficult. They always enjoyed and were interested in every single activity the teachers presented. The implementation of dolanan bocah made them feel happy and comfortable to in the lesson from the beginning of the session. They did not feel unhappy during the learning process or bored and afraid of difficult material. This condition makes it easier for the teacher to deliver the material, and the students are also able to understand the materials more clearly.

On the other hand, the role of educational media is very influential in the students' motivation to learn and their abilities, especially in terms of speaking proficiency. Appropriate and interesting media will make the lesson more interesting for the students. In addition, the subject materials will be delivered more easily, since the media acts as the intermediary between materials delivery from the teachers to the students effectively and efficiently. Suwarna [10] stated that in general the main function of instructional media is to facilitate the interactions between the teachers and the students, to help the students to learn optimally. Traditional games or dolanan bocah is one of the media used by the teachers to convey the materials as well as to improve the students' motivation to learn. The students cannot be simply asked to learn, but they must be also invited to play. Indirectly, when they play, they will learn to speak; learning while playing or playing while learning. This leads to two positive impacts for the students themselves, the first is that their motivation to learn becomes stronger, they become more enthusiastic and excited in learning to speak Bahasa Indonesia, and the second is that their ability to speak will be improved significantly.

The first cycle applied dolanan bocah ular naga, while in the second cycle dolanan bocah do mi ka do was applied. In both cycles, the students participated in the lesson enthusiastically, to the point that when they got a turn to speak, they could express their opinions and ideas related to factual problems well and confidently. An interesting learning process is able to improve the mind-set of the students, as learning by implementing dolanan bocah also assists the students in achieving more in a fun way. Dolanan bocah is implemented in groups, so that there will be interactions or communication between the learners as a means to develop their confidence in public speaking. This is in line with research conducted by Lucena and Jose in their research entitled Co-Operative Learning in Enhancing the Speaking Abilities of Students. The study shows the influence of cooperative or group learning on the students' speaking ability [11].

Apart from this, Fakhrudin [12] stated that learning or teaching is beautiful and fun, so the teachers should not force the students to understand what they are saying. Instead, the teachers should try to give the best to the students. When the teachers practice this, the students will receive and understand what the teachers are presenting or teaching more clearly. From this, it is clear that the ways in which teacher presents information to the students has an immense impact on the students' understanding, and the teachers must not teach according to their personal wishes and expectations, but according to the students' needs and conditions [13]. Playing games is one of the solutions that makes students eager to learn.

There has been a significant improvement in the students' speaking proficiency. Therefore, it can be said that learning using dolanan bocah is successful in improving the students' ability to speak. Besides this, it has also changed the students' view about speaking being a difficult lesson.

\section{CONCLUSION}

The students' ability to speak has improved significantly. This can be seen from the students' test scores as follows. In the cycle I, the average score was 71.9 with a classical completeness level of $63.3 \%$. 
Meanwhile, in cycle II, the average score changed to 82.4 with a classical completeness level of $83.3 \%$. Besides significant increases in scores, the learning process also improved with the implementation of dolanan bocah to motivate the students in learning to speak. Their motivation level is integral in determining their success in achieving the learning objectives.

\section{ACKNOWLEDGEMENTS}

The author would like to thank the headmaster of SD Negeri Mendungan 2 Yogyakarta who has given permission to conduct research at SD Negeri Mendungan.

\section{REFERENCES}

[1] Iskandarwassid, dan Sunendar, Dadang, "Strategi Pembelajaran Bahasa”, PT Remaja Rosdakarya: Bandung, 2009.

[2] Muslimin, "Perlunya Inovasi dalam Pembelajaran Bahasa dan Sastra Indonesia", Jurnal Bahasa, Sastra, dan Budaya, vol. 1, no. 1, pp. 1-8, 2011.

[3] Tarigan, Henry Guntur, "Berbicara Sebagai Suatu Keterampilan Berbahasa”, Bumi Angkasa: Bandung, 2015.

[4] Arsjad, Maidar G. \& Mukti, U.S., "Pembinaan Kemampuan Berbicara Bahasa Indonesia”, Erlangga: Jakarta, 1993.

[5] Park, Hyungsung, "Relationship between Motivation and Student's Activity on Educational Game", International Journal of Grid and Distributed Computing, vol. 5, no. 1, pp. 101-113, 2012.

[6] Semiawan, Conny, "Belajar dan Pembelajaran Prasekolah dan Sekolah Dasar”, PT Indeks: Jakarta, 2008.

[7] Marzuki, et. al., " Improving the ELF Learners' Speaking Ability Through Interactive Storytelling”, Dinamika Ilmu, vol. 16, no. 1, pp. 15-34, 2016.

[8] Nurhayati, "Berbagai Strategi Pembelajaran Bahasa dapat Meningkatkan Kemampuan Berbahasa Siswa", Lingua Jurnal Bahasa dan Sastra, vol. 9 no. 2, pp. 110-116, 2008.

[9] Wang, Ying-Jian, Shang, Hui-Fang, and Briody, Paul, "Investigating the Impact of Using Games in Teaching Children English", International Journal of Learning \& Development, vol. 1, no. 1, pp. 127-141, 2011.

[10] Suwarna, et. al., "Pengajaran Makro: Pendekatan Praktis dalam Menyiapkan Pendidik Profesional", Tiara Wacana: Yogyakarta, 2006.

[11] Lucena, Ralph J. dan Jose, Ariel E. San, "Co-Operative Learning in Enhancing the Speaking abilitys of Students: A Phenomenological Approach", International Journal of Advanced Multidisciplinary Research, vol. 3, no. 2, pp. 67-71, 2016.

[12] Fakhruddin, Asep Umar, “Tips Membuat Anak Rajin Sekolah + Hobi Belajar”, FlashBooks: Yogyakarta, 2012.

[13] Praheto, Biya Ebi. Penerapan Quantum Learning dengan Media Permainan Puzzle untuk Meningkatkan Kemampuan Membaca Aksara Jawa pada Siswa Kelas 3B SD Negeri 1 Wangon Kabupaten Banyumas. Tesis: UNS, 2013 . 